W E LFARE, S E N D 



\section{GWENDOLYN MINK}

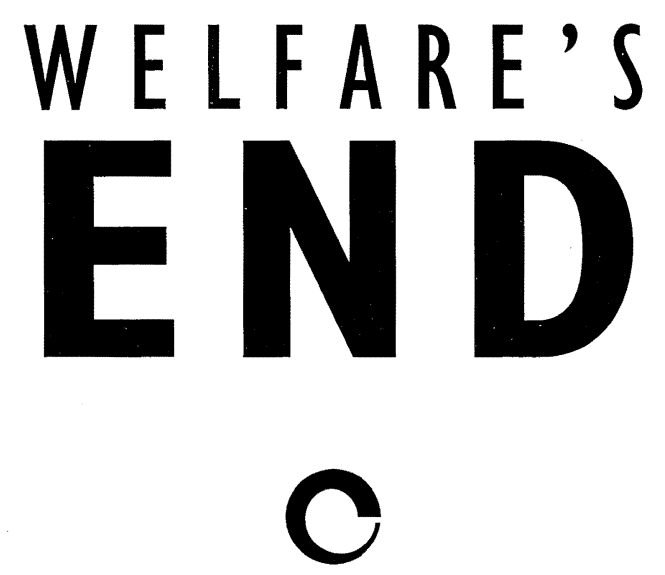

\section{Cornell University Press}

ITHACA AND LONDON 
Copyright (C) 1998 by Cornell University

All rights reserved. Except for brief quotations in a review, this book, or parts thereof, must not be reproduced in any form without permission in writing from the publisher. For information, address Cornell University Press, Sage House, 512 East State Street, Ithaca, New York 14850.

First published 1998 by Cornell University Press

First printing, Cornell Paperbacks, 2002

Printed in the United States of America

Library of Congress Cataloging-in-Publication Data

Mink, Gwendolyn, 1952-

Welfare's end / Gwendolyn Mink

p. $\mathrm{cm}$.

Includes bibliographical references and index.

ISBN 0-8014-3347-9 (cloth : alk. paper).

ISBN 0-80I4-8393-X (pbk. : alk. paper).

I. Unmarried mothers - Government policy - United States.

2. Poor mothers - Government policy - United States.

3. Welfare recipients - United States.

4. Public welfare- United States.

5. Public welfare - United States-History-20th century.

6. United States-Social policy I. Title

HV700.5.M56 1998

$362.83^{\prime} 928^{\prime} 0973-\mathrm{dc2l} \quad 97-38838$

Cornell University Press strives to use environmentally responsible suppliers and materials to the fullest extent possible in the publishing of its books. Such materials include vegetable-based, low-VOC inks and acid-free papers that are either recycled, totally chlorine-free, or partly composed of nonwood fibers. Books that bear the logo of the FSC (Forest Stewardship Council) use paper taken from forests that have been inspected and certified as meeting the highest standards for environmental and social responsibility. For further information, visit our website at www.cornellpress.cornell.edu.

$\begin{array}{llllllll}5 & 6 & 7 & 8 & 9 & 10 & \text { Cloth printing }\end{array}$

$\begin{array}{lllllllllll}1 & 2 & 3 & 4 & 5 & 6 & 7 & 8 & 9 & 10 & \text { Paperback printing }\end{array}$ 
for my parents,

John Francis Mink and Patsy Takemoto Mink 
